\title{
Trends in social exposure to SARS-Cov-2 in France. Evidence from the national socio-epidemiological cohort - EPICOV
}

\author{
Josiane Warszawski ${ }^{1,2}$, Laurence Meyer ${ }^{1,2}$, Jeanna-Eve Franck ${ }^{3}$, Delphine Rahib ${ }^{4}$, Nathalie \\ Lydié $^{4}$, Anne Gosselin ${ }^{5,6}$, Emilie Counil ${ }^{5}$, Robin Kreling ${ }^{1}$, Sophie Novelli ${ }^{1}$, Remy Slama ${ }^{7,8}$, \\ Philippe Raynaud ${ }^{9}$, Guillaume Bagein ${ }^{9}$, Vianney Costemalle ${ }^{9}$, Patrick Sillard ${ }^{10}$, Toscane \\ Fourie $^{11}$, Xavier de Lamballerie ${ }^{11}$, Nathalie Bajos ${ }^{3,12}$, Epicov Team* \\ 1 INSERM CESP U1018, Université Paris-Saclay, Le Kremlin-Bicêtre, France \\ ${ }^{2}$ AP-HP Epidemiology and Public Health Service, Service, Hôpitaux Universitaires Paris-Saclay, Le \\ Kremlin-Bicêtre, France \\ ${ }^{3}$ Iris - Institut de Recherche Interdisciplinaire sur les enjeux sociaux, Inserm, Aubervilliers, \\ France \\ ${ }^{4}$ Santé Publique France, Saint-Maurice France \\ ${ }^{5}$ French Institute for Demographic Studies (INED) \\ ${ }^{6}$ French Collaborative Institute on Migrations/CNRS, Aubervilliers, France \\ ${ }^{7}$ Institut thématique de Santé Publique, INSERM, Paris France \\ ${ }^{8}$ Inserm, CNRS, Team of Environmental Epidemiology applied to Reproduction and Respiratory \\ Health, Institute for Advanced Biosciences, University Grenoble Alpes, Grenoble, France \\ ${ }^{9}$ DREES - Direction de la Recherche, des Etudes, de l'évaluation et des statistiques, Paris, France \\ ${ }^{10}$ Institut National de la statistique et des études économiques, Montrouge, France \\ ${ }^{11}$ Unité des Virus Emergents, UVE, Aix Marseille Univ, INSERM 1207, IRD 190 FR \\ ${ }^{12}$ Ecole des Hautes Etudes en Sciences Sociales, Paris, France
}

* Epicov Team : Josiane Warszawski (co-principal investigator) and Nathalie Bajos (coprincipal investigator), Guillaume Bagein, François Beck, Emilie Counil, Florence Jusot, Nathalie Lydie, Claude Martin, Laurence Meyer, Philippe Raynaud, Alexandra Rouquette, Ariane Pailhé, Delphine Rahib, Patrick Sicard, Rémy Slama, Alexis Spire.

Keywords: COVID-19, seroprevalence, population-based cohort, random sample, risk factors, social and ethno-racial inequalities

Word count: abstract $=248$ words ; text $=2893$ words ; 2 figures, 4 tables, Supporting material: 2 tables 
medRxiv preprint doi: https://doi.org/10.1101/2021.10.25.21265456; this version posted October 26, 2021. The copyright holder for this preprint (which was not certified by peer review) is the author/funder, who has granted medRxiv a license to display the preprint in perpetuity.

\section{Abstract}

Background: We aimed to study whether social patterns of exposure to SARS-CoV-2 infection changed in France throughout the year 2020, in light to the easing of social contact restrictions.

Methods: A population-based cohort of individuals aged 15 years or over was randomly selected from the national tax register to collect socio-economic data, migration history, and living conditions in May and November 2020. Home self-sampling on dried blood was proposed to a $10 \%$ random subsample in May and to all in November. A positive anti-SARSCoV-2 ELISA IgG result against the virus spike protein (ELISA-S) was the primary outcome. The design, including sampling and post-stratification weights, was taken into account in univariate and multivariate analyses.

Results: Of the 134,391 participants in May, 107,759 completed the second questionnaire in November, and respectively 12,114 and 63,524 were tested. The national ELISA-S seroprevalence was 4.5\% [95\%CI: 4.0\%-5.1\%] in May and 6.2\% [5.9\%-6.6\%] in November. It increased markedly in 18-24-year-old population from $4.8 \%$ to $10.0 \%$, and among secondgeneration immigrants from outside Europe from $5.9 \%$ to $14.4 \%$. This group remained strongly associated with seropositivity in November, after controlling for any contextual or individual variables, with an adjusted OR of 2.1 [1.7-2.7], compared to the majority population. In both periods, seroprevalence remained higher in healthcare professions than in other occupations.

Conclusion: The risk of Covid-19 infection increased among young people and secondgeneration migrants between the first and second epidemic waves, in a context of less strict social restrictions, which seems to have reinforced territorialized socialization among peers. 


\section{Introduction}

Social determinants contribute to socioeconomic, ethno-racial and spatial inequalities in COVID-19 exposure and severity.(1,2) Their role may change over time according to the stringency or duration of social contact restrictions,(3) and vaccination policies. African, Asian and other ethnic minorities were disproportionately affected by SARS-CoV-2 in Europe and North America during the first epidemic wave.(4)'(5)'(6)'(7)'(8) However, in the UK, the difference in age-standardized COVID-19 mortality between people with black ethnic background and the white population decreased markedly between the first and second waves.(9)

France has been severely affected by COVID-19. The first wave peaked two weeks after the first lockdown initiated on 17th March, in a context of mask shortages and little availability of PCR tests. The first lockdown, which ended on 11th May 2020, after a dramatic decrease to a very low incidence rate, was very strict, with closure of schools, universities, cultural and social venues, shops except for essential supply, teleworking, and limitation of outdoor circulation.

The second wave started slowly at the end of August, despite a wide-scale distribution of masks and free access to PCR and antigenic tests. Following a period of mandatory physicaldistancing and curfew with territorial variations, a second national lockdown was instated from 30 October to 15 December. It was less restrictive than the first, with no school closure and extended list of shops authorized to remain open. Between the first and second lockdown, teleworking was encouraged. Unlike the first lockdown which caused widespread suspension of both social and professional life, the second occurred after a long period of restriction measures maintaining considerable barriers to extra-professional social life but leaving more opportunities to get together from the summer. 
Most analysis of social and ethnic disparities are based on mortality, hospitalization, and virologic PCR data. Here, we aimed to study the social dynamics of the epidemic between the end of the first lockdown in May and the second in November 2020, using the French national EpiCoV cohort, a large random population-based seroprevalence study(10), enabling identification of changes in factors associated with seropositivity in the context of the easing of social contact restrictions.

\section{Materials and Methods}

\section{Study design}

Individuals aged 15 years or older living in France were randomly selected from the FIDELI administrative sampling framework, covering $96.4 \%$ of the population, providing postal addresses for all, and e-mail addresses or telephone numbers for $83 \%$. The sampling design is detailed elsewhere.(10) Differential sampling was used to ensure oversampling of the less densely populated départements (i.e French administrative districts), and lowerincome categories. Residents in nursing homes for elderly persons were excluded. All selected individuals were contacted by post, e-mail and text messages, with up to seven reminders. In the first round in May, computer-assisted-web interviews (CAWI) or computerassisted-telephone interviews (CATI) were offered to a random $20 \%$ subsample. The remaining $80 \%$ were assigned to CAWI exclusively. All first-round respondents were eligible for the second in November 2020.

\section{Home capillary blood self-sampling for serological testing}

This was proposed during the web/telephone questionnaire to a national random subsample in May, and to all respondents in November. Dried-blood spots were collected on 903Whatman paper (DBS) kits sent to each participant agreeing to blood sampling, mailed to three biobanks (Bordeaux, Amiens, Montpellier) to be punched with a PantheraTM machine 
(Perkin Elmer). Eluates were processed in a virology laboratory (Unité des virus Emergents, Marseille) with commercial ELISA kits (Euroimmun®, Lübeck, Germany) to detect antiSARS-CoV-2 antibodies (IgG) against the S1 domain of the viral spike protein (ELISA-S), according to the manufacturer's instructions.

\section{Outcome}

SARS-Cov-2 seroprevalence was estimated as the proportion of individuals tested with an ELISA-S ratio $\geq 1.1$, according to the threshold specified by the manufacturer.

\section{Exposure}

Contextual living conditions included administrative geographical area, population density in the municipality of residence, whether the neighbourhood was defined as socially deprived with prioritizing of socio-economic interventions, the number of people in the household, the household per capita income decile, and whether any other household member had had a positive virological PCR or Antigen test since January 2020. Individual characteristics included gender, age, personal and parental migration history, educational level, current occupation (collected with more detail in November), tobacco use, and body mass index, number of contacts and face mask use outside home in the week before the second-round interview.

\section{Ethics and regulatory issues}

The survey was approved by CNIL (the French data protection authority) (ref: MLD/MFI/AR205138) and the ethics committee (Comité de Protection des Personnes Sud M editerranee III 2020-A01191-38) on April 2020, and by the "Comité du Label de la Statistique 
Publique". The serological results were sent to the participants by post with information about interpreting individual test results.

\section{Statistical analyses}

We first repeated the same univariate and multivariate analyses on the May and November samples to estimate, for each period, the seroprevalence on national level and by geographical area, contextual variables, housing conditions, and individual characteristics, and to study changes in the strength of their associations with the presence of antibodies between these two periods. We then considered the subsample of people tested negative in May (ELISA-S ratio $<0.7$ ), to study associations with positive serology in November, as a measure of the incidence of new infections between the two periods. Finally, we performed an additional multivariate analysis on the November sample, as it was much larger and included more detailed information than in May, that we added step by step in order to study the role of socio-economic and migration status more fully.

\section{Non-response adjustment weights}

Final calibrated weights were calculated to correct for non-response, as detailed elsewhere (Warszawski et al., 2021), for first and second round. Response homogeneity groups were derived from the sampling weight divided by the probability of response estimated with logit models adjusted for auxiliary variables potentially linked to both the response mechanism and the main variables of interest in the EpiCov survey. The Fideli sampling frame provided a wide range of auxiliary variables, including sociodemographics, income, quality of contact information, and contextual variables at territorial level, such as population density, proportion of people below the poverty line, obtained from geo-referenced information. Variables collected in the first round were added as auxiliary variables to adjust 
non-response models for the second round. First-step weights estimated from the percentage of respondents in each homogeneity group were calibrated according to the margins of the population census data and population projections for age categories, gender, departement, educational level, and region, to decrease the variance and the residual bias for variables correlated with margins.

The sampling design was taken into account, with SAS proc survey and STATA svy procedures, to estimate prevalences, using logit transformed confidence limits that stay within the interval [0,1], crude and adjusted odds ratios with logistic regression models, and to perform statistical tests.

\section{Results}

Among the 134391 respondents to the first-round questionnaire in May 2020, 107759 (80.2\%) completed the second-round questionnaire in November 2020 (Fig 1). Serological tests were performed in mainland France on 12114 participants for the first round (median date: May $21^{\text {st }} 2020$; IQR: $18^{\text {th }}-28^{\text {th }}$ May), and 63524 for the second (November $24^{\text {th }} 2020$; IQR: $18^{\text {th }}$ November $-4^{\text {th }}$ December).

The national seroprevalence (ELISA-S ratio $\geq 1.1$ ) increased from 4.5\% [95\%CI: $4.0-5.1 \%$ ] in May to $6.2 \%$ [5.9-6.6\%] in November, with wide disparities between départements from under $2 \%$ to $13 \%$ (Figure 2 ; Supporting table S1).

In both periods, seroprevalence was significantly higher among individuals living in highly densely populated municipalities, in socially deprived neighbourhoods and in large households (Table 1). The strength of the association with household size was weaker in November than in May. 
Seroprevalence, which tended to be higher among women than men in May $(5.0 \%$ versus $3.9 \% ; \mathrm{p}=0.054)$, was similar between men and women in November $(6.1 \%$ and $6.3 \% ; \mathrm{p}=0.52)$

(Table 2). Seroprevalence increased with higher diploma levels, and was associated with a Ushaped curve with family per capita income, with lowest rates in the central decile especially in May. Prevalence remained nearly twice as high among healthcare professionals as among people with other occupations, whether self-reported as essential or not, respectively $11.3 \%$ and $6.4 \%$ in November. Detailed analysis of professional occupations in November showed the highest seroprevalences in hospital professions (physicians, nurses and assistant nurses), two to three times higher than for other occupations, including private physicians, pharmacists, teachers and workers in essential stores. Daily smokers were at lower risk of having antibodies than occasional, former or non-smokers.

The major changes in seroprevalence between May and November 2020 concerned age and migration status. In May 2020, the highest prevalence was observed among middle-aged people ( $8.3 \%$ in $35-44$ years old) while in November 2020 , it concerned the youngest $(9.6 \%$ and $9.9 \%$ respectively in the $15-17$ and 18-24 age groups). In May 2020, prevalence was significantly higher among immigrants born outside Europe (9.2\% compared to $5.9 \%$ among second-generation immigrants from outside Europe, and $4.1 \%$ in the French-born population), but the increased risk disappeared after adjustment for living conditions (Table 3). In contrast, in November 2020, seroprevalence was higher in both first (13.3\%) and second (14.4\%) generation immigrants from outside Europe, compared to 5.3\% among French-born and 6.0\% among European immigrants, and they remained at higher risk even after adjustment for living conditions (adjusted odds ratio respectively: 2.1 [1.7-2.8] and 2.2 [1.8-2.9]). 
medRxiv preprint doi: https://doi.org/10.1101/2021.10.25.21265456; this version posted October 26, 2021. The copyright holder for this preprint (which was not certified by peer review) is the author/funder, who has granted medRxiv a license to display the preprint in perpetuity.

All rights reserved. No reuse allowed without permission.

In order to understand the overexposure of non-European immigrants and their descendants in November 2020, detailed analyses were performed (Supporting table S2), taking into account behaviours related to social distancing strategies self-reported over the week before the interview (number of prolonged contacts, mask use in the street, family or festive outings) and BMI. Associations with migration status remained unchanged. The analysis was also restricted to highly densely populated areas, and the overexposure of the second generation immigrants from outside Europe remained.

Results from the analysis of incidence of new infections between May and November was consistent with changes in seroprevalence (Table 4). Overall, 3.8\% [3.1-4.7\%] of 7515 people with no IgG antibodies in May were positive in November. The proportion of new infections was the highest in the 18-24 age group, among second-generation immigrants from outside Europe, among people living in socially deprived neighbourhoods, and among healthcare professionals. Neither household size, diploma nor family income were associated with new infections between May and November.

\section{Discussion}

Seroprevalence in France increased slowly from the end of the first lockdown to the second, from 4.5\% [95\%CI: 4.0-5.1\%] in May 2020 to 6.2\% [5.9-6.6\%] in November 2020. Seroprevalence estimated in November probably underestimates the cumulate incidence from the start of the epidemic, as the level of antibodies wanes with time.(11-13) However only 8.3\% [7.3-9.4] of participants tested twice were positive at least once, and the highest prevalence rates were under $20 \%$ even in the most affected regions. At the end of 2020 , the level of herd immunity in the general population in France remained low. Wide geographical disparities, with continental eastern and central areas the most affected, and western oceanic areas the least, could partly reflect the residual impact of the first strict national lockdown which stopped the spread of the virus from the north-east. (14) 
Between May and November 2020 seroprevalence increased much more among young people, while the middle-aged population was mainly affected during the first wave. This change is likely to be explained by more infections during the summer holidays and autumn, consistent with the higher positivity rate on PCR and antigenic tests reported to French SiDep surveillance systems between June and November 2020, ranging from $4.7 \%$ among 2029-year-olds to $3.1 \%$ among 40-59-year-olds and $1.7 \%$ among 70-79-year-olds.

The second major change was the increased seroprevalence among descendants of nonEuropean immigrants (second-generation immigrants), independently of their younger age. In May 2020, seroprevalence was twice as high among first-generation immigrants from outside Europe as in the majority population, i.e. neither immigrants nor their descendants, and this was mainly explained by residence in a densely-populated area and a large household. In November 2020, prevalence was three times higher among both non-European immigrants and their descendants, reflecting a strong increase in new infections in the second generation between May and November. Adjustment for age accounted for only part of this increase. Mostly, the association remained independent of socio-economic and living conditions, geographical area, mask use and number of prolonged contacts. Populations of non-European first and second-generation immigrants were as compliant with barrier measures as others in March and November (data not shown). Nor was this explained by differences in tobacco use, comorbidities or BMI. Similar results were observed when the analysis was restricted to highly-densely populated municipalities, and urban areas where most immigrants reside, or to areas the most affected by Covid-19.

African Americans, Hispanics, and other ethnic minority groups were disproportionately affected by SARS-CoV-2, as mostly documented during the first epidemic wave in terms of diagnosed infection, hospitalization,(6)'(8) and mortality.(7)'(8) Among potential reasons for higher incidence or severity related to ethnicity, biological susceptibilities have been 
hypothesized,(15)'(16,17) but without evidence.(18) Inequalities in mortality could be primarily driven by differences in exposure to infection.(19) In England, there was a marked reduction in the difference in age-standardized COVID-19 mortality between people from black ethnic backgrounds and people from the white group between first and second wave.(9) Some minority ethnic populations have excess risks of testing positive for SARS-CoV-2 and of adverse COVID-19 outcomes compared with the white population, even after taking account of differences in socio-demographic, clinical, and household characteristics.(20)

Our study, based on repeated general population seroprevalence measures, showed that while the overexposure to Covid-19 infection of first-generation immigrants was strongly linked to their living conditions at the beginning of the epidemic, the overexposure observed six months later for the first and especially the second generation, who have more social contacts more than their elders, is not the result of a lesser respect for barrier gestures or of more frequent outings than the native-born (supplementary table 1). It could result from microsocial structural effects, because of the phenomena of socio-spatial segregation(21) and territorialized socialization.(22) Second-generation immigrants are very often grouped together, facilitating the circulation of the virus in social groups where the prevalence is higher.

Relationships between seropositivity and population density in the residence area, family income and diploma tended to be weaker in November than in May. This could suggest a protective role of the widespread use of masks in working and public areas, and testing strategies before visiting family. In a national survey in the UK, having patient-facing role and working outside home was an important risk factor in the first but not the second wave.(23) However, despite wide availability of surgical masks after severe shortage during the first epidemic wave, seroprevalence among healthcare professionals remained twice as 
high as among individuals with other occupations in November, similar to May, with the highest rates among hospital physicians, nurses and assistant nurses. The seroprevalence was similar in May and November while the proportion of new infections was much higher than in other occupations, which could suggest that health-care professionals were infected early during the first wave, with possibly higher proportions of seroreversion in that population because IgG levels decrease with time. This increased risk was not explained by sociodemographic or living conditions, except for medical students where the association was partly explained by their younger age. The $11 \%$ seroprevalence found in May is in line with the $8.5 \%$ found in Europe during the first wave in a meta-analysis,(24) with few studies on the risk of nosocomial transmission among health-care worker.(25)

\section{Strengths}

The EpiCov cohort is one of the largest socio-epidemiological random population-based cohorts providing Covid-19 seroprevalence estimate among individuals aged 15 years and over. Most seroprevalence surveys were conducted during the first epidemic wave.(26)'(27)'(28) EpiCov identified the population most affected by the spread of the virus in the population since initial spread, providing a basis for evaluating subsequent changes in light with epidemiological context and access to preventive strategies. People living below the poverty line were intentionally over-represented in the sampling, and detailed socio-economic and migration data was obtained. We were therefore able to perform a powerful analysis focusing on social inequalities.

The home self-sampling with DBS detection of SARS CoV-2 antibodies was ideally suited to the context of the first lockdown to limit self-selection bias. 
The estimates provided here were weighted for non-response. Many auxiliary demographic and socio-economic variables were available from the sampling framework, which made it possible to correct a large part of the non-response bias.

\section{Limitations}

The EpiCov study had several limitations. It does not cover elderly people living in nursing homes. The Euroimmun ELISA-S test has a sensitivity of $94.4 \%$, according to the manufacturer's cutoff. It has been evaluated in various studies, which reported specificity ranging from $96.2 \%$ to $100 \%$ and sensitivity ranging from $86.4 \%$ to $100 \% .(29,30)$ Anti-SarsCov2 IgG antibody levels have been reported to decline more or less rapidly, particularly among the elderly and subjects with mild or asymptomatic forms.(11-13) However, factors associated with the incidence of new infections between May and November, analysed on the subsample tested in both rounds, were consistent with changes in prevalence pattern.

\section{Conclusion}

The role of living conditions on the risk of SARS-CoV-2 infection decreased between the first and second epidemic waves, possibly partly due to the widespread availability of masks and virological tests at population level. Nevertheless, in November 2020, in a context of less restricted social contacts than during the first lockdown, seroprevalence remained higher among healthcare professionals than among other professionals, and strongly increased among young people and racial minorities. These populations need special attention, especially for adherence to vaccination policies.

\section{References}

1. Bambra C, Riordan R, Ford J, Matthews F. The COVID-19 pandemic and health inequalities. J Epidemiol Community Health. 2020 Jun 13;jech-2020-214401. 
medRxiv preprint doi: https://doi.org/10.1101/2021.10.25.21265456; this version posted October 26, 2021. The copyright holder for this preprint (which was not certified by peer review) is the author/funder, who has granted medRxiv a license to display the preprint in perpetuity.

All rights reserved. No reuse allowed without permission.

2. Dorn A van, Cooney RE, Sabin ML. COVID-19 exacerbating inequalities in the US. The Lancet. 2020 Apr 18;395(10232):1243-4.

3. Bajos N, Jusot F, Pailhé A, Spire A, Martin C, Meyer L, et al. When lockdown policies amplify social inequalities in COVID-19 infections: evidence from a cross-sectional population-based survey in France. BMC Public Health. 2021 Apr 12;21:705.

4. Pareek M, Bangash MN, Pareek N, Pan D, Sze S, Minhas JS, et al. Ethnicity and COVID-19: an urgent public health research priority. Lancet Lond Engl. 2020;395(10234):1421-2.

5. Hayward SE, Deal A, Cheng C, Crawshaw A, Orcutt M, Vandrevala TF, et al. Clinical outcomes and risk factors for COVID-19 among migrant populations in high-income countries: A systematic review. J Migr Health. 2021;3:100041.

6. Sze S, Pan D, Nevill CR, Gray L, Martin CA, Nazareth J, et al. Ethnicity and clinical outcomes in COVID-19: A systematic review and meta-analysis. EClinicalMedicine. 2020 Dec;29:100630.

7. Mackey K, Ayers CK, Kondo KK, Saha S, Advani SM, Young S, et al. Racial and Ethnic Disparities in COVID-19-Related Infections, Hospitalizations, and Deaths: A Systematic Review. Ann Intern Med. 2021 Mar;174(3):362-73.

8. Mude W, Oguoma VM, Nyanhanda T, Mwanri L, Njue C. Racial disparities in COVID-19 pandemic cases, hospitalisations, and deaths: A systematic review and meta-analysis. J Glob Health. 11:05015.

9. Nafilyan V, Islam N, Mathur R, Ayoubkhani D, Banerjee A, Glickman M, et al. Ethnic differences in COVID-19 mortality during the first two waves of the Coronavirus Pandemic: a nationwide cohort study of 29 million adults in England. Eur J Epidemiol. 2021 Jun;36(6):605-17.

10. Warszawski J, Bajos N, Barlet $\mathrm{M}$, Lamballerie $\mathrm{X}$ de, Rahib D, Lydié $\mathrm{N}$, et al. A national mixedmode seroprevalence random population-based cohort on SARS-CoV-2 epidemic in France: the socio-epidemiological EpiCov study. medRxiv. 2021 Feb 26;2021.02.24.21252316.

11. Arkhipova-Jenkins I, Helfand M, Armstrong C, Gean E, Anderson J, Paynter RA, et al. Antibody Response After SARS-CoV-2 Infection and Implications for Immunity?]: A Rapid Living Review. Ann Intern Med. 2021 Jun;174(6):811-21.

12. Pérez-Olmeda M, Saugar JM, Fernández-García A, Pérez-Gómez B, Pollán M, Avellón A, et al. Evolution of antibodies against SARS-CoV-2 over seven months: experience of the Nationwide Seroprevalence ENE-COVID Study in Spain [Internet]. Infectious Diseases (except HIV/AIDS); 2021 Mar [cited 2021 Jun 9]. Available from: http://medrxiv.org/lookup/doi/10.1101/2021.03.11.21253142

13. Shioda K, Lau MSY, Kraay ANM, Nelson KN, Siegler AJ, Sullivan PS, et al. Estimating the Cumulative Incidence of SARS-CoV-2 Infection and the Infection Fatality Ratio in Light of Waning Antibodies. Epidemiology. 2021 Jul;32(4):518-24.

14. Cauchemez S, Kiem CT, Paireau J, Rolland P, Fontanet A. Lockdown impact on COVID-19 epidemics in regions across metropolitan France. Lancet Lond Engl. 2020;396(10257):1068-9.

15. Khunti K, Singh AK, Pareek M, Hanif W. Is ethnicity linked to incidence or outcomes of covid-19? BMJ. 2020 Apr 20;369:m1548. 
medRxiv preprint doi: https://doi.org/10.1101/2021.10.25.21265456; this version posted October 26, 2021. The copyright holder for this preprint (which was not certified by peer review) is the author/funder, who has granted medRxiv a license to display the preprint in perpetuity. All rights reserved. No reuse allowed without permission.

16. Kalyanaraman B. Do free radical NETwork and oxidative stress disparities in African Americans enhance their vulnerability to SARS-CoV-2 infection and COVID-19 severity? Redox Biol. 2020 Sep 15;37:101721.

17. Singh U, Hernandez KM, Aronow BJ, Wurtele ES. African Americans and European Americans exhibit distinct gene expression patterns across tissues and tumors associated with immunologic functions and environmental exposures. Sci Rep. 2021 May 10;11:9905.

18. Raisi-Estabragh Z, McCracken C, Bethell MS, Cooper J, Cooper C, Caulfield MJ, et al. Greater risk of severe COVID-19 in Black, Asian and Minority Ethnic populations is not explained by cardiometabolic, socioeconomic or behavioural factors, or by $25(\mathrm{OH})$-vitamin D status: study of 1326 cases from the UK Biobank. J Public Health Oxf Engl. 2020 Aug;42(3):451-60.

19. Ward H, Atchison C, Whitaker M, Ainslie KEC, Elliott J, Okell L, et al. SARS-CoV-2 antibody prevalence in England following the first peak of the pandemic. Nat Commun. 2021 Dec;12(1):905.

20. Mathur R, Rentsch CT, Morton CE, Hulme WJ, Schultze A, MacKenna B, et al. Ethnic differences in SARS-CoV-2 infection and COVID-19-related hospitalisation, intensive care unit admission, and death in 17 million adults in England: an observational cohort study using the OpenSAFELY platform. Lancet Lond Engl. 2021 May 8;397(10286):1711-24.

21. Floch J-M. Standards of living and segregation in twelve French metropolises. Econ Stat. 2017;497(1):73-96.

22. Hipp JR, Faris RW, Boessen A. Measuring 'neighborhood:Constructing network neighborhoods. Soc Netw [Internet]. 2012 [cited 2021 Sep 1];34(1). Available from: https://escholarship.org/uc/item/28d4217b

23. Pouwels KB, House T, Pritchard E, Robotham JV, Birrell PJ, Gelman A, et al. Community prevalence of SARS-CoV-2 in England from April to November, 2020: results from the ONS Coronavirus Infection Survey. Lancet Public Health. 2021 Jan;6(1):e30-8.

24. Galanis P, Vraka I, Fragkou D, Bilali A, Kaitelidou D. Seroprevalence of SARS-CoV-2 antibodies and associated factors in healthcare workers: a systematic review and meta-analysis. J Hosp Infect. 2021 Feb;108:120-34.

25. Abbas $M$, Robalo Nunes $T$, Martischang R, Zingg W, Iten A, Pittet D, et al. Nosocomial transmission and outbreaks of coronavirus disease 2019: the need to protect both patients and healthcare workers. Antimicrob Resist Infect Control. 2021 Jan 6;10(1):7.

26. Rostami A, Sepidarkish M, Leeflang MMG, Riahi SM, Nourollahpour Shiadeh M, Esfandyari S, et al. SARS-CoV-2 seroprevalence worldwide: a systematic review and meta-analysis. Clin Microbiol Infect. 2021 Mar;27(3):331-40.

27. Lai C-C, Wang J-H, Hsueh P-R. Population-based seroprevalence surveys of anti-SARS-CoV-2 antibody: An up-to-date review. Int J Infect Dis. 2020 Dec;101:314-22.

28. Bobrovitz N, Arora RK, Cao C, Boucher E, Liu M, Donnici C, et al. Global seroprevalence of SARSCoV-2 antibodies: A systematic review and meta-analysis. PloS One. 2021;16(6):e0252617. 
medRxiv preprint doi: https://doi.org/10.1101/2021.10.25.21265456; this version posted October 26, 2021. The copyright holder for this preprint

(which was not certified by peer review) is the author/funder, who has granted medRxiv a license to display the preprint in perpetuity.

All rights reserved. No reuse allowed without permission.

29. Patel EU, Bloch EM, Clarke W, Hsieh Y-H, Boon D, Eby Y, et al. Comparative Performance of Five Commercially Available Serologic Assays To Detect Antibodies to SARS-CoV-2 and Identify

Individuals with High Neutralizing Titers. J Clin Microbiol. 2021 Jan 21;59(2):e02257-20.

30. Kohmer N, Westhaus S, Rühl C, Ciesek S, Rabenau HF. Clinical performance of different SARSCoV-2 IgG antibody tests. J Med Virol. 2020 Oct;92(10):2243-7. 


\section{The EPICOV study group}

Josiane Warszawski ${ }^{1,2}$, Nathalie Bajos ${ }^{9}$ (joint principal investigators), Guillaume Bagein, François Beck ${ }^{4}$, Emilie Counil ${ }^{10}$, Florence Jusot ${ }^{11}$, Nathalie Lydié ${ }^{4}$, Claude Martin ${ }^{12}$, Laurence Meyer ${ }^{2}$, Philippe Raynaud ${ }^{7}$, Alexandra Rouquette ${ }^{1,2}$, Ariane Pailhé ${ }^{10}$, Delphine Rahib $^{4}$, Patrick Sillard ${ }^{8}$, Alexis Spire ${ }^{12}$.

INSERM CESP U1018, Université Paris-Saclay, Le Kremlin-Bicêtre, France

2 AP-HP Epidemiology and Public Health Service, Service, Hôpitaux Universitaires ParisSaclay, Le Kremlin-Bicêtre, France

${ }^{3}$ Unité des Virus Emergents, UVE, Aix Marseille Univ, IRD 190, INSERM 1207, IHU Méditerranée Infection, Marseille, France

${ }^{4}$ Santé Publique France, Saint-Maurice France

5 Institut thématique de Santé Publique, INSERM, Paris France

6 Inserm, CNRS, Team of Environmental Epidemiology applied to Reproduction and Respiratory Health, Institute for Advanced Biosciences, University Grenoble Alpes, Grenoble, France

7 DREES - Direction de la Recherche, des Etudes, de l'évaluation et des statistiques, Paris, France

${ }^{8}$ Institut National de la statistique et des études économiques, Montrouge, France

${ }^{9}$ IRIS, INSERM, EHESS, CNRS Aubervilliers, France

${ }^{10}$ INED, France

${ }^{11}$ Université Paris Dauphine, France

${ }^{12}$ CNRS, France

The EPICOV study group : J Warszawski, N Bajos (Co-PI), G Bagein, F Beck, E Counil, F Jusot,' N Lydié, C Martin, L Meyer, P Raynaud, A Rouquette, A Pailhé, D Rahib, P Sillard, A Spire. 


\section{STATEMENT FORM}

\section{Financial disclosure statement}

This research was supported by research grants from Inserm (Institut National de la Santé et de la Recherche Médicale) and the French Ministry for Research, by Drees-Direction de la Recherche, des Etudes, de l'Evaluation et des Statistiques, and the French Ministry for Health, and by the Région Ile de France.

Dr. Bajos has received funding from the European Research Council (ERC) under the European Union's Horizon 2020 research and innovation programme (grant agreement No. [856478])

This project has also received funding from the European Union's Horizon 2020 research and innovation programme under grant agreement No 101016167, ORCHESTRA (Connecting European Cohorts to Increase Common and Effective Response to SARS-CoV-2 Pandemic).

\section{Competing interests}

No competing interests

\section{Ethics approval and consent to participate}

This $1^{\text {st }}$ and $2^{\text {nd }}$ rounds of the EpiCov study were performed in accordance with the relevant guidelines and regulations, approved by the CNIL (the French data protection authority) (ref: MLD/MFI/AR205138) on April $25^{\text {th }}, 2020$, last revised on October $2^{\text {nd }} 2020$ and the ethics committee (Comité de Protection des Personnes Sud Meediterranee III 2020-A01191-38) on April $25^{\text {th }} 2020$, last revised on September $2^{\text {nd }}, 2020$. The survey was also approved by the "Comité du Label de la Statistique Publique". All participants or their legally authorized representatives had provided informed consent to participation in this study as detailed below.

An information letter was sent by post to all individuals selected at first round, mentioning the purpose of the survey, the method of data collection, the categories of data collected, the free and voluntary nature of participation in the study, the contact details of the data processors, the length of time the data will be kept, as well as the methods for exercising their rights. The letter was also sent by email and/or shorter SMS, when available, and posted on the EpiCov website https://www.epicov.fr/. For minors (all aged 15 years old or more), the letter/e-mail/ SMS were sent to the parents including a letter to be given to the selected minor of the household, which indicated that his/her parents were informed and had right to access their responses unless he/she does not want them to. In this case, he/she has to indicate refusal in a specific question asked at beginning of the web or telephone questionnaire. Considering the full active information process, responding to the questionnaire was considered to be the expression of an express consent. Similar process was used at the second round to contact and inform all respondents of the first round.

A kit for home self-sampling on dried blood in order to perform a Covid-19 serological test was sent to participants who expressed their consent, proposed to a subsample in first round and to all in second round. At each round, the consent was collected during the web or telephone questionnaire administration, after presenting purpose, practical procedures and recall of their rights. The kit was accompanied of an information letter which also recalled the purpose of the blood sample, the rights of the participants, and detailed practical procedures. 
The fact of performing and sending by post the blood sample was then considered as an express consent for the realization of the serologic test.

Serological results were sent to the participants with information about interpreting individual test results.

\section{Consent for publication}

Not concerned

\section{$\underline{\text { Availability of data and materials }}$}

Anonymous aggregated data for the first round are available online. The EpiCov dataset is available for research purpose concerning the first round, and will be available by March 2022 concerning the second round for research purpose on CASD (https://www.casd.eu/), after submission to approval of French Ethics and Regulatory Committee procedure (Comité du Secret Statistique, CESREES and CNIL). Access to anonymized individual data underlying the findings may be available before the planned period, on request to the corresponding author, to be submitted to approval of ethics and reglementary Committee for researchers who meet the criteria for access to data. 


\section{Authors' contributions}

Josiane Warszawski and Nathalie Bajos were responsible for the conception and design of the research study. Patrick Sillard, was responsible of the sampling design from the Fideli frame, and supervised modeling non-response weights at first round. Xavier de Lamballerie was responsible of the choice, realization and interpretation of serological tests. Delphine Rabib and Nathalie Lydie were responsible for the whole coordination process concerning serological data acquisition from home self-sampling kit, including conceiving and sending kits to participants, DBS return to biobank and transfer of eluate from biobank to the virological laboratories for analysis. Josiane Warszawski and Jeanna-Eve Franck were responsible of the statistical analysis of this paper. Josiane Warszawski, Nathalie Bajos, Laurence Meyer and Jeanna-Eve Frank wrote the first draft of this paper. The remaining authors of the EpiCov study group contributed to elaboration of the questionnaire, sampling and data acquisition, quality control, and logistics. All these authors reviewed this paper, contributed to data interpretation, and approved the final version.

\section{$\underline{\text { Acknowledgements }}$}

We sincerely thank all the participants in the EpiCoV study.

We warmly thank the INSERM staff, including, in particular, Carmen Calandra, Karim Ammour, Jean-Marc Boivent, Jean-Marie Gagliolo, Frédérique Le Saulnier, and Frédéric Robergeau, who worked with considerable dedication and commitment to make it possible to develop, in record time, and to maintain all regulatory, budgetary, technical, and logistical aspects of the EpiCov study.

We warmly thank the staff of Santé publique France, and especially Lucie Duchesne, who played a major role in organisation and quality assurance for the seroprevalence component of the EpiCov study.

We thank the CRB biobanks staff, and especially their heads, Dr Isabelle Pellegrin, and Julien Jeanpetit (Centre Hospitalier Universitaire Robert Pellegrin, Bordeaux, France), Pr Edouard Tuaillon Centre de Ressources Biologiques du CHU de Montpellier), Dr Yves-Edouard Herpe (Centre de Ressources Biologiques Biobanque de Picardie), Pr Jacqueline Deloumeaux (Centre biologique du CHU de la Guadeloupe), Dr Rémi Neviere ( CeRBiM, Centre de Ressources Biologiques de la Martinique), Julien Eperonnier, Estelle Nobecourt (Centre de Ressources Biologiques de la Réunion) for the quality of DBS sample management of the EpiCov study. We thank the biobank team in Inserm SC10, particularly Sophie Circosta.

We also thank the staff of the UVE virology department, for the high-quality management of such a large number of serological assays.

We thank the staff of DREES and INSEE, for their collaboration in the implementation of the study, methodological input, sample selection, and the complex development of weights to correct for non-response.

We thank the Ipsos staff, including Christophe David and Valérie Blineau in particular, for their major contribution to the quality of data collection 
Figure 1. Flowchart: the national EpiCov cohort, round 1 (May 2020) and round 2 (November 2020)

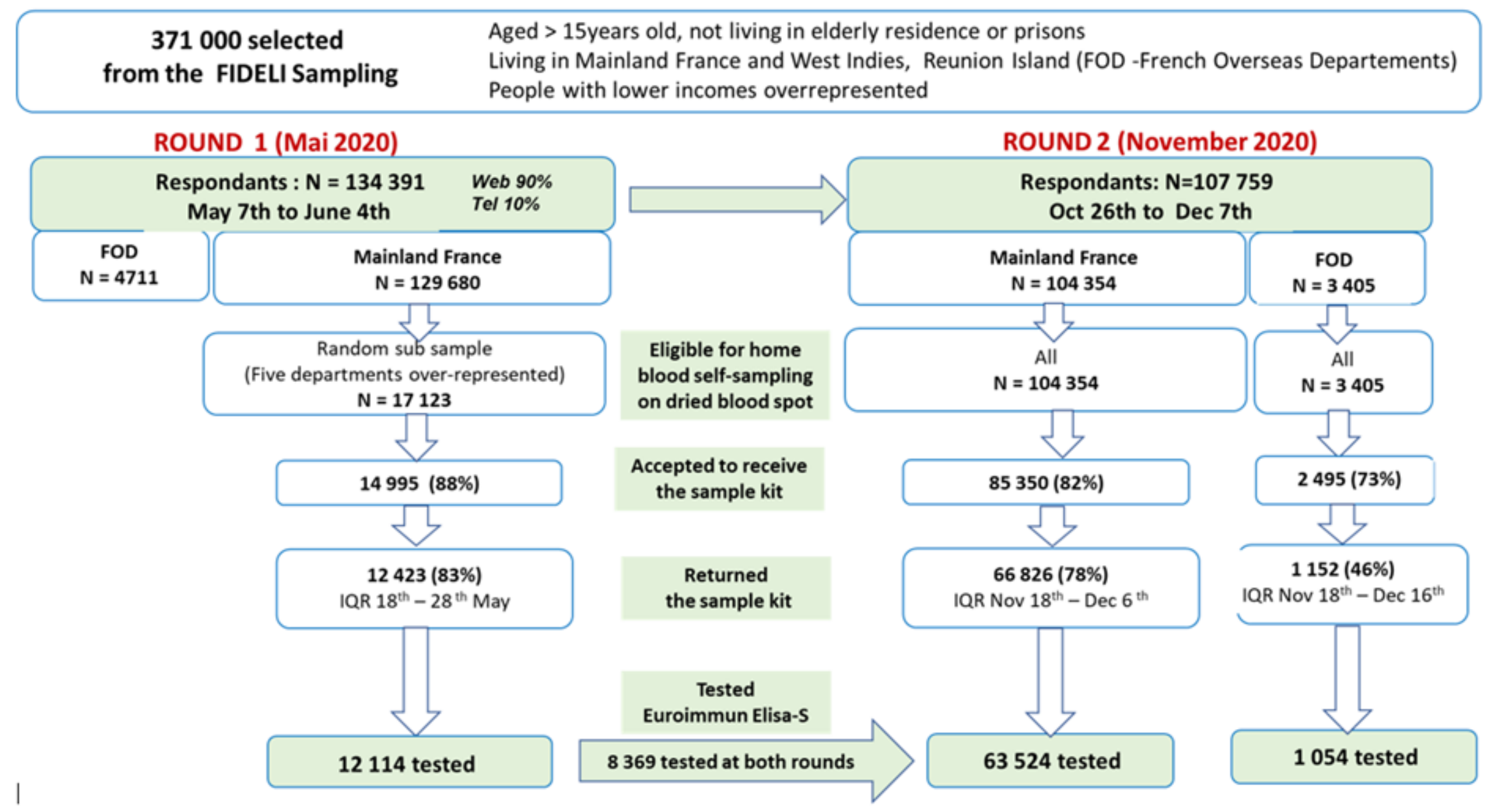


Figure 2: Geographical prevalence of SARS-CoV-2 antibodies ${ }^{1}$ among people living in France ${ }^{2}$ at the end of the first lockdown: the national EpiCov cohort, round 1 (May 2020) and round 2 (November 2020). Legend : ${ }^{1}$ Euroimmun ELISA-S on Dried blood spot; home sampling by finger prick. $/{ }^{2}$ People aged 15 or over, residing in mainland France, but not in nursing homes for elderly people or prisons.

Seroprevalence in May 2020

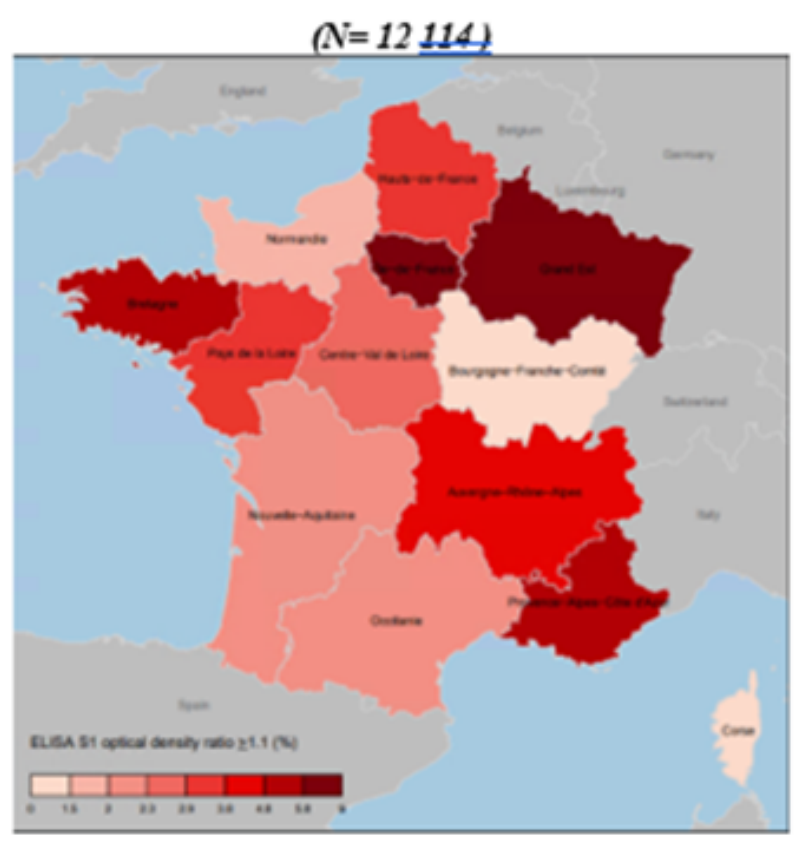

Seroprevalence in November 2020

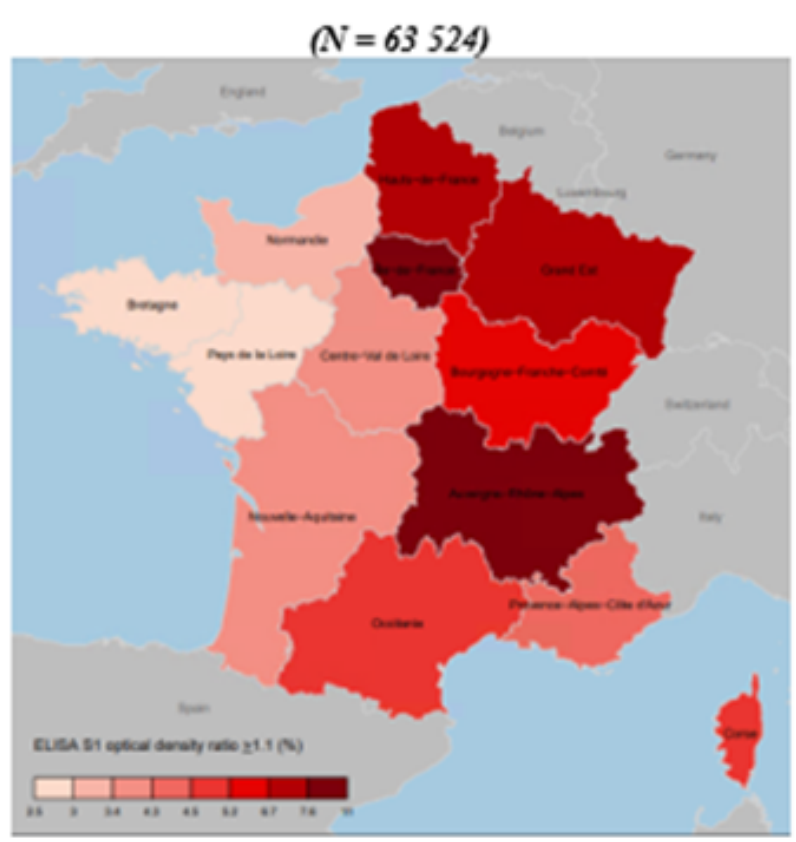

Proportion tested positive in May or November $\mathbf{2 0 2 0}$ (N= 8369 tested at both rounds)

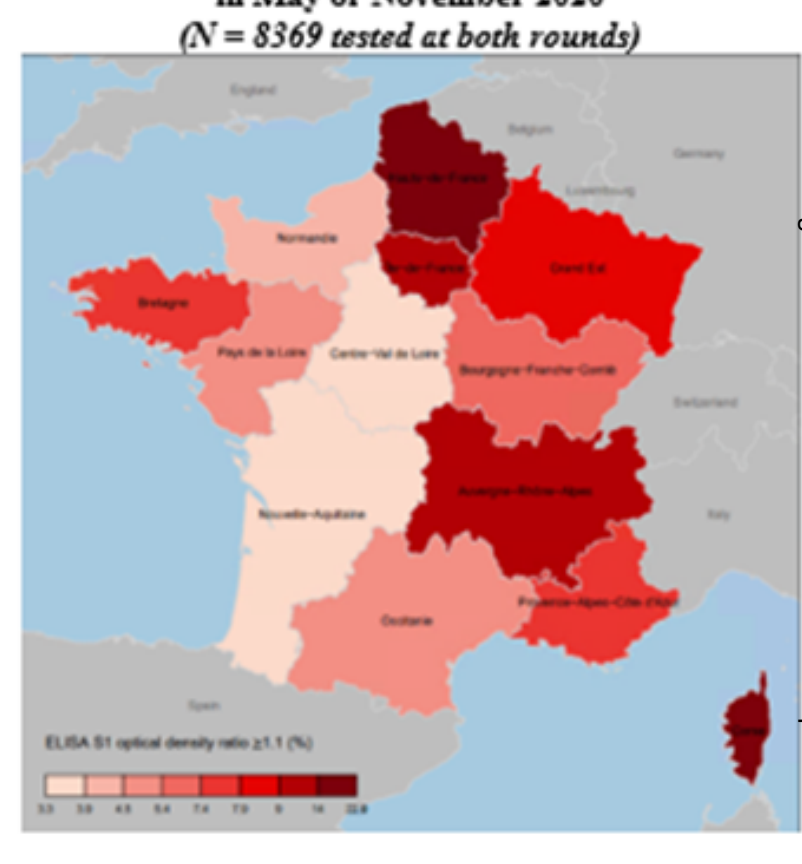


medRxiv preprint doi: https://doi.org/10.1101/2021.10.25.21265456; this version posted October 26, 2021. The copyright holder for this preprint (which was not certified by peer review) is the author/funder, who has granted medRxiv a license to display the preprint in perpetuity.

Table 1: SARS-Cov-2 SEROP Phtevase people living in mainland France ${ }^{2}$ : the national EpiCov cohort, rounds 1 \& 2

\begin{tabular}{|c|c|c|c|c|c|c|c|c|c|c|}
\hline \multirow[b]{2}{*}{ All } & \multicolumn{5}{|c|}{ ELISA $\geq 1.1$ (May 2020) $^{3}$} & \multicolumn{5}{|c|}{ ELISA $\geq 1.1$ (November 2020$)^{3}$} \\
\hline & $\begin{array}{c}\text { Total } \\
12114\end{array}$ & $\begin{array}{c}\text { cases } \\
785 \\
\end{array}$ & $\begin{array}{c}\% \\
4.5 \\
\end{array}$ & $\begin{array}{c}\mathrm{Cl} 95 \% \\
{[4.0-5.1]}\end{array}$ & $\mathbf{p}$ & $\begin{array}{l}\text { Total } \\
63524\end{array}$ & $\begin{array}{l}\text { cases } \\
3943 \\
\end{array}$ & $\begin{array}{c}\% \\
6.2 \\
\end{array}$ & $\begin{array}{c}\mathrm{Cl} 195 \% \\
{[5.9-6.6]}\end{array}$ & $\mathbf{P}$ \\
\hline \multicolumn{11}{|l|}{ Number of people in household } \\
\hline 1 & 1665 & 74 & 2.1 & [1.4-3.1] & $<0.001$ & 10377 & 570 & 5.2 & {$[4.5-5.9]$} & $<0.001$ \\
\hline 2 & 4266 & 203 & 2.7 & {$[2.2-3.4]$} & & 24994 & 1331 & 4.9 & {$[4.6-5.3]$} & \\
\hline 3 & 2268 & 173 & 5.1 & {$[4.0-6.6]$} & & 10902 & 741 & 6.5 & {$[5.8-7.2]$} & \\
\hline 4 & 2560 & 210 & 7.1 & {$[5.6-8.9]$} & & 12040 & 899 & 7.9 & {$[7.1-8.8]$} & \\
\hline 5 or more & 1349 & 125 & 8.5 & {$[6.1-11.8]$} & & 5189 & 400 & 10.1 & {$[8.7-11.8]$} & \\
\hline$\geq 1$ suspected Covid case in household & & & & & $<0.001$ & & & & & \\
\hline Living alone & 1665 & 74 & 2.1 & [1.4-3.1] & & 10377 & 570 & 5.2 & {$[4.5-5.9]$} & $<0.001$ \\
\hline No (and not living alone) & 8822 & 433 & 4.0 & {$[3.4-4.7]$} & & 37355 & 1494 & 4.1 & {$[3.8-4.5]$} & \\
\hline Yes before June 2020 & 1621 & 278 & 12.9 & {$[10.6-15.6]$} & & 4543 & 514 & 12.0 & {$[10.4-13.8]$} & \\
\hline Yes since June 2020 & & & & & & 8143 & 966 & 13.4 & {$[12.2-14.6]$} & \\
\hline Yes before and after June 2020 & & & & & & 3084 & 397 & 12.6 & [11.1-14.3] & \\
\hline \multicolumn{11}{|l|}{ Population density in municipality } \\
\hline Low & 3666 & 219 & 3.4 & {$[2.7-4.4]$} & $<0.001$ & 23647 & 1178 & 4.5 & {$[4.1-4.8]$} & $<0.001$ \\
\hline Medium & 3562 & 199 & 3.3 & {$[2.5-4.2]$} & & 18650 & 1075 & 5.4 & {$[4.9-6]$} & \\
\hline High & 4886 & 367 & 6.4 & {$[5.3-7.6]$} & & 21227 & 1690 & 8.5 & {$[7.9-9.2]$} & \\
\hline \multicolumn{11}{|l|}{ Socially-deprived neighbourhood } \\
\hline No & 11589 & 743 & 4.2 & {$[3.7-4.8]$} & 0.021 & 61840 & 3778 & 5.9 & {$[5.6-6.2]$} & $<0.001$ \\
\hline Yes & 525 & 42 & 8.2 & {$[4.7-14]$} & & 1684 & 165 & 11.2 & [8.9-14] & \\
\hline \multicolumn{11}{|l|}{ Geographical area (region) } \\
\hline 11- lle de France & 2430 & 214 & 9.0 & {$[7.3-11.2]$} & $<0.001$ & 10441 & 1021 & 11.0 & {$[10 ; 0-12.1]$} & $<0.001$ \\
\hline 24-Centre Loire & 232 & 8 & 2.4 & {$[1.2-5.0]$} & & 2527 & 107 & 4.2 & [3.1-5.7] & \\
\hline 27-Bourgogne Franche Comté & 280 & 7 & 1.5 & {$[0.6-3.4]$} & & 3056 & 195 & 5.6 & {$[4.6-6.7]$} & \\
\hline 28-Normandie & 266 & 7 & 1.5 & [0.7-3.3] & & 2788 & 115 & 3.1 & {$[2.5-3.8]$} & \\
\hline 32-Hauts de France & 1499 & 66 & 3.7 & {$[2.2-6.1]$} & & 5876 & 418 & 6.8 & {$[5.9-7.9]$} & \\
\hline 44-Grand Est & 3239 & 323 & 6.7 & {$[5.2-8.5]$} & & 6461 & 501 & 6.7 & {$[5.9-7.6]$} & \\
\hline 52-Pays de Loire & 328 & 11 & 2.9 & {$[1.6-5.3]$} & & 3869 & 148 & 3.0 & {$[2.4-3.8]$} & \\
\hline 53-Bretagne & 307 & 12 & 4.8 & {$[2.3-9.8]$} & & 3510 & 105 & 2.5 & {$[1.9-3.2]$} & \\
\hline 75-Nouvelle Aquitaine & 538 & 13 & 2.0 & [1.1-3.5] & & 5820 & 202 & 3.4 & {$[2.8-4.1]$} & \\
\hline 76-Occitanie & 560 & 19 & 2.2 & {$[1.4-3.7]$} & & 6335 & 268 & 4.5 & [3.7-5.5] & \\
\hline 84-Auvergne & 716 & 36 & 4.0 & {$[2.8-5.6]$} & & 8274 & 643 & 8.4 & {$[7.4-9.4]$} & \\
\hline 93-PACA & 1687 & 69 & 5.0 & {$[3.2-7.6]$} & & 4278 & 211 & 4.4 & {$[3.5-5.4]$} & \\
\hline 94-Corse & 32 & 0 & 0.0 & & & 289 & 9 & 4.8 & {$[1.9-11.4]$} & \\
\hline
\end{tabular}

\section{Legend}

1. Home sampling by finger prick/Euroimmun ELISA-S test

2. People aged 15 years or over residing in mainland France, outside nursing homes for elderly and prisons.

3. The sampling design is taken into account for the estimation of prevalence, confidence intervals (logit transformation) and statistical tests, with the SAS procsurvey procedure. The percentages are weighted by sampling weight (the inverse of inclusion probability), corrected for non-response weigts and calibrated on the margin of the census. The prevalences are not equal to $\mathrm{n} / \mathrm{N}$. 
medRxiv preprint doi: https://doi.org/10.1101/2021.10.25.21265456; this version posted Octoper 26,2021. The copyright holder for this preprint

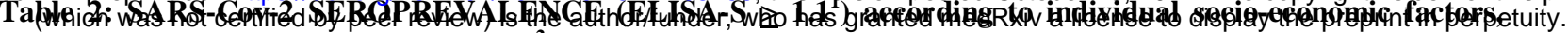

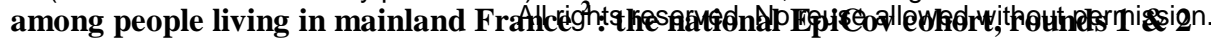

\begin{tabular}{|c|c|c|c|c|c|c|c|c|c|c|}
\hline \multirow[b]{3}{*}{ All } & \multicolumn{5}{|c|}{ ELISA $\geq 1.1{\text { (May } 2020)^{3}}^{3}$} & \multicolumn{5}{|c|}{ ELISA $\geq 1.1$ (November 2020$)^{3}$} \\
\hline & Total & cases & $\%$ & $\mathrm{Cl} 95 \%$ & $\mathbf{p}$ & Total & cases & $\%$ & $\mathrm{Cl} 95 \%$ & $\mathbf{P}$ \\
\hline & 12114 & 785 & 4.5 & {$[4.0-5.1]$} & & 63524 & 3943 & 6.2 & {$[5.9-6.6]$} & \\
\hline \multicolumn{11}{|l|}{ Gender } \\
\hline Men & 5469 & 321 & 3.9 & [3.1-4.8] & 0.052 & 27564 & 1665 & 6.1 & {$[5.7-6.6]$} & 0.459 \\
\hline Women & 6645 & 464 & 5.0 & {$[4.3-5.9]$} & & 35960 & 2278 & 6.4 & {$[6-6.8]$} & \\
\hline \multicolumn{11}{|l|}{ Age (years) } \\
\hline $15-17$ & 418 & 27 & 4.5 & {$[2.2-8.9]$} & $<0.001$ & 1438 & 128 & 9.8 & {$[7.8-12.2]$} & $<0.001$ \\
\hline $18-24$ & 1042 & 61 & 4.8 & {$[3-7.6]$} & & 4919 & 483 & 10.0 & {$[8.6-11.5]$} & \\
\hline $25-34$ & 1544 & 118 & 5.0 & [3.7-6.7] & & 6816 & 490 & 7.2 & {$[6.3-8.3]$} & \\
\hline $35-44$ & 2050 & 198 & 8.3 & {$[6.7-10.4]$} & & 10345 & 671 & 6.5 & {$[5.8-7.4]$} & \\
\hline $45-54$ & 2340 & 176 & 4.9 & {$[3.9-6.2]$} & & 12596 & 850 & 6.5 & {$[5.9-7.2]$} & \\
\hline $55-64$ & 2234 & 122 & 4.8 & {$[3.3-7.1]$} & & 12879 & 710 & 5.3 & {$[4.8-5.8]$} & \\
\hline $65-74$ & 1727 & 64 & 1.8 & {$[1.2-2.7]$} & & 10611 & 462 & 4.3 & [3.8-4.9] & \\
\hline $75+$ & 759 & 19 & 0.7 & {$[0.4-1.4]$} & & 3920 & 149 & 3.7 & {$[2.9-4.7]$} & \\
\hline \multicolumn{11}{|l|}{ Migratory status ${ }^{4}$} \\
\hline No (majority population) & 9769 & 612 & 4.1 & [3.5-4.7] & $<0.001$ & 54296 & 3172 & 5.3 & {$[5.1-5.6]$} & $<0.001$ \\
\hline \multicolumn{11}{|l|}{ Immigrant from Europe } \\
\hline First-generation & 345 & 22 & 3.8 & {$[2-6.9]$} & & 1577 & 84 & 5.2 & [3.9-6.8] & \\
\hline Second-generation & 668 & 39 & 3.8 & {$[2.4-5.9]$} & & 3164 & 197 & 6.0 & {$[4.9-7.3]$} & \\
\hline \multicolumn{11}{|l|}{ Immigrant from outside Europe } \\
\hline First-generation & 606 & 61 & 9.2 & {$[6.2-13.6]$} & & 1760 & 207 & 13.3 & [10.7-16.3] & \\
\hline Second-generation & 581 & 44 & 5.9 & {$[3.8-9.2]$} & & 1894 & 233 & 14.4 & [11.9-17.4] & \\
\hline \multicolumn{11}{|l|}{ Detailed Migratory status ${ }^{4}$} \\
\hline \multicolumn{11}{|l|}{ No (majority population) } \\
\hline Born in Mainland France & 9646 & 596 & 4.0 & $3.4-4.6$ & & 53697 & 3109 & 5.3 & {$[5.0-5.5]$} & \\
\hline Born in FOD ${ }^{5}$ & 56 & 8 & 12.4 & $5.3-26.3$ & & 301 & 32 & 7.3 & {$[4.8-11.2]$} & \\
\hline Parents born in $\mathrm{FOD}^{5}$ & 67 & 8 & 3.3 & $1.2-9.2$ & & 298 & 31 & 7.5 & {$[4.7-11.6]$} & \\
\hline \multicolumn{11}{|l|}{ Immigrant from Europe } \\
\hline First- generation & 345 & 22 & 3.8 & {$[2-6.9]$} & & 1577 & 84 & 5.2 & [3.9-6.8] & \\
\hline Second-generation & 668 & 39 & 3.8 & {$[2.4-5.9]$} & & 3164 & 197 & 6.0 & {$[4.9-7.3]$} & \\
\hline \multicolumn{11}{|l|}{ 1st generation from outside Europe } \\
\hline Born in Africa & 356 & 35 & 7.4 & $4.5-12.1$ & & 950 & 126 & 15.5 & [11.9-20.0] & \\
\hline Born in Asia or elsewhere & 250 & 26 & 13.4 & $7.1-23.7$ & & 810 & 81 & 9.4 & {$[6.8-12.8]$} & \\
\hline 2nd generation from outside Europe & 581 & 44 & 5.9 & {$[3.8-9.2]$} & & 1894 & 233 & 14.4 & [11.9-17.4] & \\
\hline Born in Africa & 385 & 29 & 6.8 & $4.0-11.4$ & & 1181 & 156 & 15.6 & {$[12.3-19.6]$} & \\
\hline Born in Asia or elsewhere & 196 & 15 & 4.1 & $1.9-8.4$ & & 713 & 77 & 12.1 & {$[8.7-16.5]$} & \\
\hline \multicolumn{11}{|l|}{ Occupation in May ${ }^{6}$} \\
\hline Healthcare profession & 578 & 74 & 11.4 & {$[8.2-15.6]$} & $<0.001$ & 3219 & 338 & 11.3 & {$[9.8-13]$} & $<0.001$ \\
\hline Other essential profession & 1219 & 99 & 5.2 & {$[3.8-7.1]$} & & 6259 & 381 & 6.4 & {$[5.3-7.7]$} & \\
\hline Non-essential profession & 4960 & 365 & 5.7 & {$[4.8-6.8]$} & & 24984 & 1619 & 6.4 & {$[5.9-6.9]$} & \\
\hline No occupation & 5356 & 247 & 3.0 & {$[2.3-3.9]$} & & 29046 & 1605 & 5.7 & {$[5.3-6.2]$} & \\
\hline \multicolumn{11}{|l|}{ Educational level } \\
\hline$<$ High school diploma & 1908 & 98 & 3.2 & {$[2.2-4.8]$} & $<0.001$ & 8496 & 488 & 5.6 & {$[4.9-6.3]$} & $<0.001$ \\
\hline High school diploma & 3922 & 204 & 3.3 & {$[2.6-4.2]$} & & 20384 & 1171 & 5.7 & {$[5.2-6.3]$} & \\
\hline Secondary first degree diploma & 2435 & 184 & 6.4 & {$[5.0-8.0]$} & & 13509 & 835 & 6.9 & {$[6.3-7.6]$} & \\
\hline$\geq$ Bachelor's degree & 3849 & 299 & 6.2 & {$[5.2-7.5]$} & & 21135 & 1449 & 7.3 & {$[6.8-7.9]$} & \\
\hline Family income per capita (deciles) & & & & & & & & & & \\
\hline D01 (lowest) & 798 & 52 & 5.7 & {$[3.2-9.9]$} & 0.016 & 3672 & 241 & 8.2 & [6.7-10] & $<0.001$ \\
\hline D02-D03 & 1430 & 86 & 4.8 & {$[3.5-6.7]$} & & 6481 & 385 & 6.2 & {$[5.3-7.3]$} & \\
\hline D04-D05 & 1718 & 97 & 3.3 & {$[2.4-4.5]$} & & 9098 & 523 & 5.3 & {$[4.7-6.0]$} & \\
\hline D06-D07 & 2423 & 128 & 2.9 & {$[2.2-3.8]$} & & 13252 & 785 & 5.9 & {$[5.4-6.5]$} & \\
\hline D08-D09 & 3332 & 237 & 5.5 & {$[4.5-6.7]$} & & 18724 & 1147 & 6.1 & {$[5.7-6.6]$} & \\
\hline D10 & 2112 & 159 & 6.0 & {$[4.7-7.6]$} & & 10880 & 766 & 7.0 & {$[6.5-7.6]$} & \\
\hline Tobacco use & & & & & & & & & & $<0.001$ \\
\hline Daily smoker & 1995 & 69 & 2.8 & {$[2.0-4.0]$} & 0.032 & 8949 & 266 & 2.7 & {$[2.3-3.2]$} & \\
\hline Occasional smoker & 470 & 33 & 5.1 & {$[3.1-8.2]$} & & 2941 & 196 & 7.8 & {$[6.2-9.7]$} & \\
\hline Ex smoker since epidemic & & & & & & 879 & 48 & 5.4 & {$[3.3-8.6]$} & \\
\hline Ex-smoker before epidemic & 3888 & 253 & 4.5 & [3.5-5.8] & & 15895 & 940 & 5.7 & [5.2-6.3] & \\
\hline Non-smoker & 5756 & 430 & 5.1 & [4.3-6.0] & & 34819 & 2492 & 7.5 & [7.1-8] & \\
\hline
\end{tabular}


medRxiv preprint doi: https://doi.org/10.1101/2021.10.25.21265456; this version posted October 26, 2021. The copyright holder for this preprint Legend was not certified by peer review) is the author/funder, who has granted medRxiv a license to display the preprint in perpetuity.

1. Home sampling by finger prick/ Eurroim reserved. No resuse allowed without permission.

2. People aged 15 years or over residing in mainland France, outside nursing homes for elderly and prisons.

3. The sampling design is taken into account for the estimation of prevalence, confidence intervals (logit transformation) and statistical tests, with the SAS procsurvey procedure. The percentages are weighted by sampling weight (the inverse of inclusion probability), corrected for non-response weigts and calibrated on the margin of the census. The prevalences are not equal to $\mathrm{n} / \mathrm{N}$.

4. Migratory status: Majority population = persons born in France who are neither first nor second-generation immigrants / First-generation immigrants: born non-French outside France and living permanently in France (including those who subsequently acquired French nationality) / Second-generation immigrants: born and living in France, with at least one parent a first-generation immigrant

5. FOD : French overseas départements

6. Self-reported in round 1: a) Healthcare professions Include medical and paramedical professionals, firefighters, pharmacists and ambulance drivers (but not including hospital cleaners, for example),.; b) Other essential professions included: Home helps or housekeepers, food shop workers, delivery drivers, public transportation drivers, cab drivers, bank customer services or reception staff, petrol station employees, police officers, postal workers, cleaning staff, security guards, construction workers, truck drivers, farmers and social workers), also self-reported. 
medRxiv preprint doi:https://doi.org/10.1101/2021.10.25.21265456; this version posted October 26 , 2021 The copyright holder for this preprint

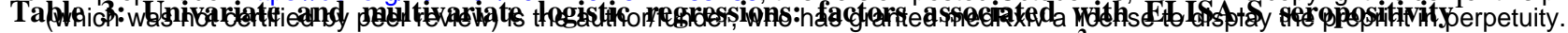

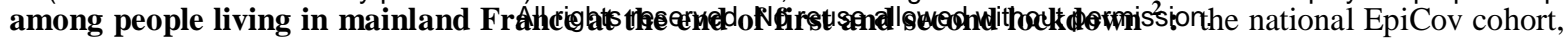
rounds $1 \& 2$

\begin{tabular}{|c|c|c|c|c|c|c|c|c|}
\hline & \multicolumn{4}{|c|}{ ELISA $\geq 1.1$ (May 2020) } & \multicolumn{4}{|c|}{ ELISA $\geq 1.1$ (Novem ber 2020) } \\
\hline & $\mathrm{OR}_{\text {crude }}$ & $95 \% \mathrm{Cl}^{3}$ & $\mathrm{OR}_{\mathrm{adj}}$ & $95 \% \mathrm{Cl}^{3}$ & $\mathrm{OR}_{\text {crude }}$ & $95 \% \mathrm{Cl}^{3}$ & $\mathbf{O R}_{\text {adj }}$ & $95 \% \mathrm{Cl}^{3}$ \\
\hline \multicolumn{9}{|l|}{ Individual characteristics } \\
\hline Gender & $P=0.053$ & & $\begin{array}{c}P=0.08 \\
5\end{array}$ & & $P=0.45$ & & $P=0.88$ & \\
\hline Men & ref & & ref & & ref & & ref & \\
\hline Women & 1.3 & {$[1.0-1.7]$} & 1.3 & {$[1.0-1.7]$} & 1.0 & [0.9-1.2] & 1.0 & [0.9-1.1] \\
\hline Age (years) & $P<0.001$ & & $\begin{array}{c}P=0.00 \\
3\end{array}$ & & $P<0.001$ & & $P<0.001$ & \\
\hline $15-17$ & 6.3 & {$[2.3-17.1]$} & 3.2 & [1.0-10.3] & 2.8 & {$[2.0-4.1]$} & 2.0 & [1.4-3.0] \\
\hline $18-24$ & 6.9 & {$[3.0-15.6]$} & 2.9 & {$[1.2-6.0]$} & 2.9 & {$[2.2-3.9]$} & 2.2 & {$[1.6-3.0]$} \\
\hline $25-34$ & 7.2 & [3.4-14.9] & 2.5 & {$[1.5-8.2]$} & 2.0 & {$[1.5-2.7]$} & 1.6 & {$[1.1-2.3]$} \\
\hline $35-44$ & 12.3 & {$[6.1-25.0]$} & 5.4 & {$[2.4-12.5]$} & 1.8 & {$[1.4-2.4]$} & 1.3 & [0.9-1.8] \\
\hline $45-54$ & 7.0 & [3.4-14.2] & 3.6 & {$[1.6-8.4]$} & 1.8 & {$[1.4-2.4]$} & 1.5 & [1.1-2.1] \\
\hline $55-64$ & 6.9 & [3.1-15.1] & 4.8 & {$[2.0-11.6]$} & 1.5 & [1.1-1.9] & 1.4 & [1.0-1.9] \\
\hline $65-74$ & 2.5 & {$[1.1-5.5]$} & 2.3 & {$[1.0-5.2]$} & 1.2 & {$[0.9-1.5]$} & 1.2 & {$[0.9-1.6]$} \\
\hline $75+$ & ref & & ref & & ref & & ref & \\
\hline Migration status ${ }^{4}$ & $P=0.002$ & & $P=0.705$ & & $P<0.001$ & & $P<0.001$ & \\
\hline No (majority population) & ref & & ref & & ref & & ref & \\
\hline First-generation from Europe & 0.9 & {$[0.5-1.8]$} & 1.1 & {$[0.6-2.3]$} & 1.0 & [0.7-1.3] & 1.1 & [0.8-1.4] \\
\hline Second-generation Europe & 0.9 & {$[0.6-1.5]$} & 1.0 & {$[0.6-1.7]$} & 1.1 & [0.9-1.4] & 1.2 & [1.0-1.5] \\
\hline First-generation outside Europe & 2.4 & [1.5-3.9] & 1.6 & [0.8-3.0] & 2.7 & [2.1-3.5] & 2.0 & [1.5-2.5] \\
\hline Second-generation outside Europe & 1.5 & {$[0.9-2.5]$} & 1.1 & {$[0.6-1.9]$} & 3.0 & {$[2.4-3.8]$} & 2.1 & [1.7-2.7] \\
\hline Occupational status ${ }^{5}$ & $P<0.001$ & & $P=0.002$ & & $\mathrm{P}<0.001$ & & $P=0.001$ & \\
\hline Healthcare profession & 2.1 & [1.4-3.2] & 2.1 & [1.4-3.2] & 1.9 & {$[1.6-2.2]$} & 1.9 & {$[1.6-2.3]$} \\
\hline Other essential profession & 0.9 & {$[0.6-1.3]$} & 1.0 & [0.7-1.5] & 1.0 & {$[0.8-1.2]$} & 0.9 & [0.8-1.1] \\
\hline Non-essential profession & ref & & ref & & ref & & ref & \\
\hline No occupation & 0.5 & {$[0.4-0.7]$} & 0.8 & {$[0.6-1.2]$} & 0.9 & [0.8-1.0] & 1.0 & [0.9-1.1] \\
\hline Educational level & $P<0.001$ & & $P=0.072$ & & $\mathrm{P}<0.001$ & & $P=0.31$ & \\
\hline$<$ High school diploma & ref & & ref & & ref & & ref & \\
\hline High school diploma & 1.0 & {$[0.6-1.7]$} & 1.0 & [0.6-1.6] & 1.0 & [0.9-1.2] & 1.1 & [0.9-1.3] \\
\hline Secondary first degree diploma & 2.0 & [1.3-3.3] & 1.5 & {$[0.9-2.5]$} & 1.3 & [1.1-1.5] & 1.2 & [1.0-1.5] \\
\hline$\geq$ Bachelor's degree & 2.0 & {$[1.3-3.1]$} & 1.2 & {$[0.7-1.9]$} & 1.3 & {$[1.1-1.6]$} & 1.1 & [0.9-1.4] \\
\hline Family income per capita (deciles) & $P<0.001$ & & $P=0.004$ & & $P<0.001$ & & $P=0.009$ & \\
\hline D01 (lowest) & 2.0 & [1.0-3.9] & 1.5 & {$[0.8-2.9]$} & 1.4 & [1.1-1.8] & 1.1 & [0.8-1.3] \\
\hline D02-D03 & 1.7 & {$[1.1-2.6]$} & 1.7 & {$[1.0-2.6]$} & 1.1 & [0.9-1.3] & 0.9 & [0.7-1.1] \\
\hline D04-D05 & 1.1 & {$[0.7-1.7]$} & 1.1 & {$[0.7-1.7]$} & 0.9 & [0.8-1.0] & 0.8 & [0.7-1.0] \\
\hline D06-D07 & ref & & ref & & ref & & ref & \\
\hline D08-D09 & 1.9 & {$[1.4-2.7]$} & 1.9 & {$[1.3-2.7]$} & 1.0 & {$[0.9-1.2]$} & 1.0 & [0.9-1.2] \\
\hline D10 & 2.1 & {$[1.5-3.1]$} & 1.9 & [1.3-2.9] & 1.2 & [1.1-1.4] & 1.2 & [1.0-1.3] \\
\hline Tobacco use & $P=0.035$ & & $\mathrm{P}=0.025$ & & $\mathrm{P}<0.001$ & & $P<0.001$ & \\
\hline Daily smoker & ref & & ref & & ref & & ref & \\
\hline Occasional smoker & 1.8 & {$[1.0-3.5]$} & 2.0 & {$[1.0-4.0]$} & 3.1 & {$[2.3-4.2]$} & 2.4 & {$[1.7-3.3]$} \\
\hline Ex smoker since epidemic & & & & & 2.1 & {$[1.2-3.5]$} & 1.9 & {$[1.1-3.2]$} \\
\hline Ex-smoker before epidemic & 1.6 & {$[1.0-2.6]$} & 1.8 & {$[1.2-2.9]$} & 2.2 & {$[1.8-2.7]$} & 2.4 & [2.0-3.0] \\
\hline Non-smoker & 1.8 & {$[1.2-2.8]$} & 1.9 & {$[1.2-2.8]$} & 3.0 & {$[2.5-3.6]$} & 2.8 & [2.3-3.5] \\
\hline \multicolumn{9}{|l|}{ Living conditions } \\
\hline Population density in municipality & $P<0.001$ & & $\mathrm{P}<0.001$ & & $\mathrm{P}<0.001$ & & $P<0.001$ & \\
\hline Low & ref & & ref & & ref & & ref & \\
\hline Medium & 1.0 & {$[0.7-1.4]$} & 1.1 & [0.8-1.6] & 1.2 & [1.1-1.4] & 1.1 & [1.0-1.3] \\
\hline High & 1.9 & {$[1.4-2.7]$} & 1.8 & {$[1.3-2.5]$} & 2.0 & {$[1.8-2.2]$} & 1.6 & [1.4-1.8] \\
\hline Socially deprived neighbourhood & $P=0.024$ & & $\mathrm{P}=0.35$ & & $<0.001$ & & $P=0.009$ & \\
\hline No & ref & & ref & & ref & & ref & \\
\hline Yes & 2.0 & [1.1-3.7] & 1.4 & {$[0.7-2.6]$} & 2.0 & {$[1.5-2.6]$} & 1.4 & [1.1-1.9] \\
\hline Number of people in household & $P<0.001$ & & $P=0.003$ & & $\mathrm{P}<0.001$ & & $P<0.001$ & \\
\hline 1 & ref & & ref & & ref & & ref & \\
\hline 2 & 1.3 & {$[0.8-2.1]$} & 1.4 & {$[0.9-2.3]$} & 1.0 & {$[0.8-1.1]$} & 1.0 & [0.8-1.2] \\
\hline 3 & 2.5 & [1.6-4.1] & 2.0 & {$[1.2-3.6]$} & 1.3 & [1.1-1.5] & 1.1 & [1.0-1.4] \\
\hline 4 & 3.6 & {$[2.2-5.8]$} & 2.5 & [1.4-4.4] & 1.6 & {$[1.3-1.9]$} & 1.4 & [1.1-1.6] \\
\hline 5 or more & 4.4 & {$[2.5-7.6]$} & 3.4 & [1.7-6.6] & 2.1 & {$[1.7-2.6]$} & 1.4 & [1.1-1.7] \\
\hline
\end{tabular}

Legend 
medRxiv preprint doi: https://doi.org/10.11.01/2021.10.25.21265456; this version posted October 26, 2021. The copyright holder for this preprint

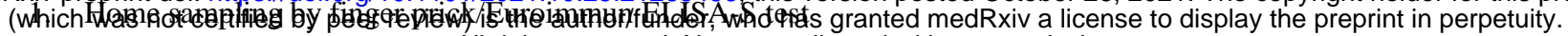

2. People aged 15 years or over All rights reserved Np reuse allowed without permission nind prisons.

3. The sampling design is taken into account for the estimation of prevalence, confidence intervals (logit transformation), crude and adjusted odds ratios, confidence intervals and statistical tests, with the SAS procsurvey procedure. The percentages are weighted by sampling weight (the inverse of inclusion probability), corrected for non-response weigts and calibrated on the margin of the census. The prevalences are not equal to $\mathrm{n} / \mathrm{N}$.

4. Migratory status: Majority population = persons born in France who are neither first nor second-generation immigrants / First-generation immigrants: born non-French outside France and living permanently in France (including those who subsequently acquired French nationality) / Second-generation immigrants: born and living in France, with at least one parent being a first-generation immigrant

5. Self-Reported in round 1: a) Healthcare professions Included medical and paramedical professionals, firefighters, pharmacists and ambulance drivers (but not including hospital cleaners, for example); b) Other essential professions included: home helps or housekeepers, food shop workers, delivery drivers, public transportation drivers, cab drivers, bank customer service or reception staff, petrol station employees, police officers, postal workers, cleaning staff, security guards, construction workers, truck drivers, farmers and social workers), also self-reported. 
medRxiv preprint doi: https://doi.org/10.1101/2021.10.25.21265456; this version posted October 26, 2021. The copyright holder for this preprint

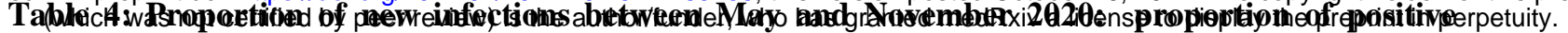

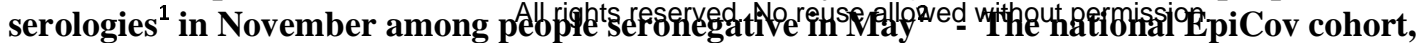

\begin{tabular}{|c|c|c|c|c|c|c|c|c|}
\hline & \multicolumn{5}{|c|}{ Proportion of new seropositive case } & \multicolumn{3}{|c|}{ Multivariate logistic regression } \\
\hline & $\mathbf{N}$ & $\mathbf{n}$ & $\%$ & $95 \% \mathrm{Cl}^{3}$ & $\mathbf{p}$ & ORadj & $95 \% \mathrm{Cl}^{3}$ & p \\
\hline Overall & 7519 & 274 & 3.8 & {$[3.1-4.7]$} & & & & \\
\hline \multicolumn{9}{|l|}{ Gender } \\
\hline Men & 3304 & 128 & 3.8 & {$[2.8-5.3]$} & 0.99 & Ref & & 0.71 \\
\hline Women & 4215 & 146 & 3.8 & {$[2.9-5.0]$} & & 1.1 & {$[0.7-1.6]$} & \\
\hline \multicolumn{9}{|l|}{ Age (years) } \\
\hline $15-17$ & 179 & 9 & 4.3 & {$[1.2-14.2]$} & 0.001 & 5.0 & {$[0.8-16.0]$} & $<0.001$ \\
\hline $18-24$ & 532 & 40 & 9.2 & {$[5.2-15.6]$} & & 4.2 & {$[1.2-15.0]$} & \\
\hline $25-34$ & 841 & 46 & 4.6 & {$[3.0-7.1]$} & & 1.6 & {$[0.4-6.3]$} & \\
\hline $35-44$ & 1180 & 43 & 2.8 & {$[1.7-4.4]$} & & 0.9 & {$[0.2-3.7]$} & \\
\hline $45-54$ & 1498 & 55 & 4.8 & [3.1-7.4] & & 2.5 & {$[0.6-9.4]$} & \\
\hline $55-64$ & 1519 & 50 & 3.3 & {$[2.2-5.1]$} & & 1.8 & {$[0.5-6.7]$} & \\
\hline $65-74$ & 1242 & 22 & 1.4 & {$[0.8-2.8]$} & & 0.8 & {$[0.2-3.0]$} & \\
\hline $75+$ & 528 & 9 & 1.6 & {$[0.5-4.7]$} & & Ref & & \\
\hline \multicolumn{9}{|l|}{ Migration status ${ }^{4}$} \\
\hline No (majority population) & 6268 & 213 & 3.7 & {$[2.8-4.7]$} & $<0.001$ & Ref & & 0.007 \\
\hline First- generation from Europe & 224 & 2 & 0.2 & {$[0.04-1.5]$} & & 0.1 & {$[0.01-0.6]$} & \\
\hline Second-generation Europe & 413 & 14 & 1.9 & {$[0.7-4.9]$} & & 0.7 & {$[0.2-1.9]$} & \\
\hline First-generation from outside Europe & 272 & 21 & 5.4 & {$[2.9-10.0]$} & & 1.7 & {$[0.8-3.9]$} & \\
\hline Second-generation outside Europe & 263 & 21 & 9.9 & {$[5.5-17.1]$} & & 2.8 & {$[1.2-6.1]$} & \\
\hline \multicolumn{9}{|l|}{ Occupational status ${ }^{5}$} \\
\hline Healthcare profession & 355 & 28 & 7.1 & {$[4.0-12.0]$} & 0.17 & 2.3 & {$[1.2-4.7]$} & 0.09 \\
\hline Other essential profession & 683 & 26 & 4.6 & {$[2.6-7.9]$} & & 1.2 & {$[0.6-2.6]$} & \\
\hline Non-essential profession & 3052 & 120 & 4.2 & {$[2.9-6.1]$} & & Ref & & \\
\hline No occupation & 3428 & 100 & 3.2 & {$[2.3-4.4]$} & & 1.0 & {$[0.5-2.0]$} & \\
\hline \multicolumn{9}{|l|}{ Educational level } \\
\hline$<$ High school diploma & 1045 & 28 & 1.9 & {$[1.0-3.5]$} & 0.03 & Ref & & 0.05 \\
\hline High school diploma & 2366 & 78 & 4.0 & {$[2.8-5.6]$} & & 2.5 & {$[1.1-5.7]$} & \\
\hline Secondary first degree diploma & 1518 & 58 & 5.4 & {$[3.2-8.9]$} & & 3.2 & {$[1.4-7.2]$} & \\
\hline$\geq$ Bachelor's degree & 2590 & 110 & 4.7 & {$[3.4-6.3]$} & & 2.5 & {$[1.1-6.0]$} & \\
\hline \multicolumn{9}{|l|}{ Family income per capita (deciles) } \\
\hline D01(lowest) & 395 & 16 & 3.1 & {$[1.5-6.2]$} & 0.88 & 0.5 & {$[0.2-1.3]$} & 0.79 \\
\hline D02-D03 & 776 & 29 & 4.6 & {$[2.5-8.5]$} & & 1.0 & {$[0.5-2.0]$} & \\
\hline D04-D05 & 985 & 35 & 3.7 & {$[2.3-5.9]$} & & 1.0 & {$[0.5-2.0]$} & \\
\hline D06-D07 & 1522 & 46 & 3.6 & {$[2.4-5.5]$} & & Ref & & \\
\hline D08-D09 & 2258 & 80 & 3.4 & {$[2.4-4.9]$} & & 1.0 & {$[0.5-1.7]$} & \\
\hline D10 & 1428 & 60 & 4.0 & {$[2.6-6.3]$} & & 1.0 & {$[0.5-2.0]$} & \\
\hline \multicolumn{9}{|l|}{ Tobacco use } \\
\hline Daily smoker & 1159 & 28 & 2.9 & {$[1.6-5.1]$} & 0.34 & Ref & & 0.57 \\
\hline Occasional smoker & 349 & 14 & 3.9 & {$[1.8-8.3]$} & & 1.1 & {$[0.4-3.3]$} & \\
\hline Ex-smoker & 1937 & 61 & 3.2 & {$[2.2-4.6]$} & & 1.5 & {$[0.7-3.0]$} & \\
\hline Non-smoker & 4067 & 171 & 4.4 & {$[3.5-5.9]$} & & 1.6 & {$[0.8-3.0]$} & \\
\hline \multicolumn{9}{|l|}{ Population density in municipality } \\
\hline Low & 2340 & 69 & 2.2 & {$[1.6-3.2]$} & 0.020 & Ref & & 0.048 \\
\hline Medium & 2248 & 82 & 4.7 & {$[3.0-7.4]$} & & 1.9 & {$[1.1-3.3]$} & \\
\hline High & 2931 & 123 & 4.6 & {$[3.5-6.0]$} & & 1.6 & {$[0.9-2.9]$} & \\
\hline \multicolumn{9}{|l|}{ Socially deprived neighbourhood } \\
\hline No & 7246 & 257 & 3.4 & {$[2.8-4.2]$} & 0.005 & Ref & & 0.028 \\
\hline Yes & 273 & 17 & 10.6 & {$[4.8-22.0]$} & & 2.7 & {$[1.1-6.7]$} & \\
\hline \multicolumn{9}{|l|}{ Number of people in household } \\
\hline 1 & 1287 & 39 & 4.1 & {$[2.6-6.4]$} & 0.63 & Ref & & 0.75 \\
\hline 2 & 3004 & 90 & 3.2 & {$[2.1-5.0]$} & & 0.7 & {$[0.4-1.4]$} & \\
\hline 3 & 1260 & 52 & 3.5 & {$[2.2-5.6]$} & & 0.6 & {$[0.3-1.3]$} & \\
\hline 4 & 1357 & 69 & 4.4 & {$[3.1-6.3]$} & & 0.7 & {$[0.4-1.4]$} & \\
\hline 5 or more & 606 & 24 & 5.2 & [2.8-9.5] & & 0.8 & [0.4-2.0] & \\
\hline
\end{tabular}

Legend

6. Home sampling by finger prick/Euroimmun ELISA-S test

7. People aged 15 years or over residing in mainland France, outside nursing homes and prisons.

8. The sampling design is taken into account for the estimation of prevalence, confidence intervals (logit transformation), crude and adjusted odds ratios, confidence intervals and statistical tests, with the SAS 
medRxiv preprint doi: https://doi.org/10.1101/2021.10.25.21265456; this version posted October 26, 2021. The copyright holder for this preprint

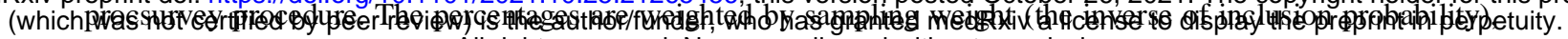

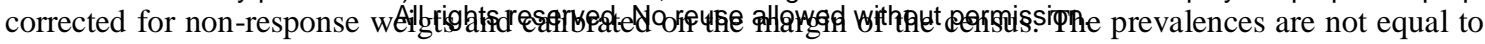
$\mathrm{n} / \mathrm{N}$.

9. Migratory status: Majority population = persons born in France who are neither first nor second-generation immigrants / First-generation immigrants: born non-French outside France and living permanently in France (including those who subsequently acquired French nationality) / Second-generation immigrants: born and living in France, with at least one parent being a first-generation immigrant

10. Self-reported in round 1: a) Healthcare professions Included medical and paramedical professionals, Firefighters, pharmacists and ambulance drivers (but not including hospital cleaners, for example); b) Other essential profession included: Home helps or housekeepers, food shop workers, delivery drivers, public transportation drivers, cab drivers, bank customer service or reception staff, petrol station employees, police officers, postal workers, cleaning staff, security guards, construction workers, truck drivers, farmers and social workers), also self-reported. 
medRxiv preprint doi: https://doi.org/10.1101/2021.10.25.21265456; this version posted October 26, 2021. The copyright holder for this preprint

(which was not certified by peer review) is the author/funder, who has granted medRxiv a license to display the preprint in perpetuity.

All rights reserved. No reuse allowed without permission. 